\title{
Pesantren Education and Charismatic Leadership: A Qualitative Analysis Study on Quality Improvement of Islamic Education in Pondok Pesantren Nurul Jadid Paiton, Probolinggo
}

\author{
M. Syafiq Humaisi ${ }^{1, *}$, Muhammad Thoyib ${ }^{2}$, Imron Arifin ${ }^{3}$, Ali Imron ${ }^{3}$, A. Sonhadji \\ ${ }^{1}$ Department of Educational Management Postgraduate of Universitas Negeri Malang, Indonesia \\ ${ }^{2}$ Islamic Education Major, Tarbiyah Faculty, State Islamic Institute Ponorogo, Indonesia \\ ${ }^{3}$ Education Management Major Graduate Program Universitas Negeri Malang, Indonesia
}

Copyright $\odot 2019$ by authors, all rights reserved. Authors agree that this article remains permanently open access under the terms of the Creative Commons Attribution License 4.0 International License

\begin{abstract}
The current research is aimed at knowing and analysing; 1) the charismatic leadership in improving the quality of Islamic educational process, 2) the charismatic leadership in improving the supervising quality, 3) the charismatic leadership in improving the quality of educational outputs. This study employs a qualitative approach with case study design, and it applies a modified inductive analysis method. The research is conducted at Pondok Pesantren Nurul Jadid Paiton Probolinggo. The results of the study show that charismatic leadership in improving the quality of pesantren education consists of developing teachers' competence through formal education (Dual mode system, bachelor degree for high school graduates and master degree for bachelors in both Indonesia and abroad) and informal education (training and workshop of main curriculum), the visiting teachers, and facilities. Besides education, it also improves the quality of student supervision, which includes developing the dormitory, the supervising program, and the quality time. Furthermore, it also improves the outcome quality of pesantren, which is strengthening the network among domestic and international alumni, interboarding schools and universities, and entrepreneurship training and community service.
\end{abstract}

Keywords Charismatic Leadership, Pesantren Education, Islamic Education

\section{Introduction}

The existence of modern pesantren in Indonesia is quite apprehensive if it is not seriously concerned. It is possible that this old Islamic educational institution remains only the name someday, without leaving real 'inscription of glory' during the current globalisation. Through more serious attention, Pesantren will better develop and become more competitive in both quantity and quality for its high potential to accommodate most human resources from the middle to the lower class. Thus, it has a bigger chance, later on, to take part in various sectors of competition, including science, which is badly needed in this century. It is in line with the view of Kennedy, cited in Colling [1], "change is a way of life. Those who look to the past or present will miss the future". Thus, to create the reformation of Islamic education in Pondok Pesantren, we should adhere to the challenges of the future global competition to be able to compete well.

Various efforts are supposed to be made by both traditional and modern Pondok Pesantren to maintain the existence of Indonesia. A hard struggle may lead it to survive and gain the trust of stakeholders. The effort is influenced by how serious and strong the performance is in managing the institution, one of which is applying effective and efficient leadership. Besides, a manager should also be able to utilise all the potentials of Pondok Pesantren for the better quality of Islamic education. Building the culture of charismatic leadership might be one of the solutions. It is believed that charismatic leadership may give a positive influence on the implementation of the educational process in Pondok Pesantren. Muhaimin [2] confirms that the charisma of a pesantren leader is essential. When it is properly established, the manager will be able to give a positive effect on Pondok Pesantren.

There are several reasons why conducting the current research in Pondok Pesantren Nurul Jadid Paiton Probolinggo. Firstly, the leader (kiai) of the boarding 
school is institutional charismatic that he can develop the institution of modern pesantren well in both quantity and quality. The alumni widely spread in various universities abroad can develop their educational institutions in their respective regions. Therefore, it is feasible to follow up in the form of a more comprehensive study. Secondly, Probolinggo is known for Kota Santri (the city of Islamic religious students), and there are a large number of Islamic educational institutions. Thus, access to information related to the development and innovation of education is automatically up-to-date. This assumption lets the researcher try to find out the answer by conducting more-comprehensive research. It is hoped that the final result can be used as one of the academic references for Islamic educational institution, especially Pondok Pesantren which has a formal educational institution, to increase their competitiveness in the future. Thirdly, in addition to Zainul Hasan Genggong, Darullughah Walkaramah, Pesantren Qur'aniyah, and Badridduja Probolinggo, Nurul Jadid is a relatively large boarding school over East Java. Fourthly, the boarding school has a strong commitment to improve the quality of pesantren education by enhancing leadership management.

The current theory of charismatic leadership is a lot influenced by the ideas of the early social scientist, Max Weber [3]. Charisma is a Greek word which means "gloriously-inspired blessing", such as the ability to perform miracles or to predict the future. Weber [3] uses the term to describe an influence which is not based on the tradition or formal authority but instead on the perception of followers that leaders are blessed with extraordinary qualities, which also works in education. According to Weber, the charisma occurs when there is a social crisis. A leader emerges with a radical vision offering solution for it. He attracts followers who believe in that vision. Then, they are successful in some aspects, by which they feel the idea is visible. In the end, they believe that leaders are exceptional (a person with outstanding power). According to Mardiyah [4], charismatic leaders are born because they are God's given and/or they can maintain authority. Charisma will be more likely associated with educational leaders who act unconventionally to achieve that vision. The initial version of the theory does not explain the process of charismatic leadership influence, but the interview by Conger [5] provides more insight into the rationale why the followers of charismatic education leaders are committed to the duty or mission [6]. The influence is also caused by the internalisation of new values and beliefs. Conger [5] affirms that it is essential for followers to adopt leaders' attitudes and beliefs about work rather than merely imitating the artificial aspects of their behaviour such as temperament, gestures, and speech patterns. A charismatic educational leader expresses that inspiring vision serves as a source of intrinsic motivation to carry out the mission of his educational organisation.

Pesantren is one of Indonesian education which undoubtedly plays a significant role in educating the nation for tens of years, even more than a century. Today, it is required to bring Islamic vision, modernity, and humanity, so that it is compatible with the development of the era [7]. Ziemek [8] explains that pondok pesantren is a specific religious educational institution in Indonesia. Once, it is better known as an Islamic educational institution, an institution used to disseminate and study about Islam. Along with the changes and developments of the times, there is a shift upon values, structures, and views in every aspect of human life, one of which is related to education. About education, pesantren has various problems. Besides, it should be able to maintain positive values as its attribute. It also should welcome new things (innovation), which are what the society demands in modern life. Through the ability to adapt to the current changes, pesantren is evolving and shifting with various religious, educational institutions, such as recitation of yellow books (salaf), private school (madrasah), state school, colleges and skill training [9].

Azm [10] affirms that there are at least four normative principles of charismatic leadership for education leader to be a democratic, firm and Islamic leader:

(a) The Principle of Commitment(to be responsible for the organisation)

Islam has outlined in the hadith that everyone is a leader (at least for himself), and he is demanded to be accountable for that leadership. A prospective leader is supposed to understand the meaning of responsibility for the mandate entrusted is not in vain.

(b) Ethical principles of tauhid (the indivisible oneness concept of monotheism in Islam)

Islamic leadership is developed on the principle of ethical monotheism. The main requirement of a leader outlined by God in His word in Surah Ali Imran (3) verse 118.

(c) The principle of justice

To maintain the balance of interest, the principle of justice must be maintained. It is intended to avoid the stigma of injustice such as marginal groups and others. This is in line with the word of God in surah Shaad (38) verse 26.

\section{(d) The principle of simplicity.}

Rasulullah SAW stated that a leader is supposed to serve the people, not on the other way around. He says in the hadith of Abu Na'im, "The leader of people is basically their servant".

Tampubolon [11] asserts that quality is the appropriateness of a product to the need of the customers. In the context of Islamic education, especially Pondok Pesantren, the statement normatively contains the urgency of quality for the existence of an Islamic educational institution, especially Pondok Pesantren in the competition among Indonesian competition. A quality directly 
demonstrates the characteristics and identity of the Islamic educational institution. A better quality of Islamic educational institutions (Pondok Pesantren) will automatically get assurance from the community (social assurance) to always use the service. Besides, an excellent Islamic educational institution will always have a coherent relevance to the needs of society. This notion is an implication of quality management credibility demonstrated by Islamic education institution (Pondok Pesantren).

Moreover, good quality will lead Islamic educational institutions into an excellent opportunity to control the implementation of educational programs by the quality standard. It will also develop and improve the outcome quality to be more qualified, dynamic, and competitive, evolving by the demands of the times and global competition. It confirms the high vitality of quality management within Islamic education including Pondok Pesantren. It is the key success of Pondok Pesantren which will always survive and exist among the growing global competition.

Atkinson [12] put it into 3: firstly, the quality of education can be seen from the outcome which is the essence of all effort in education. The common measurement of the graduates is their role after they go into society or competition in the workplace. It means that the quality level of education, including Islamic educational institutions (Pondok Pesantren), is illustrated by how far the graduates can fulfill the demands of society or workplace as typically listed in the general purpose of education (in Indonesian context, it is the national goal of education and the general purpose of educational institutions). Secondly, another way of measuring the quality of education is evaluating the immediate outcomes. It is manifested in the students' behaviour (in the form of knowledge, skills and attitudes) after they complete the education. The immediate outcome as the measurement of quality education covers both cognitive and non-cognitive aspects, measurable or not, and predicted or previously unexpected. The students' behavioural measurement is not only a written test but also other types of tests. Thirdly, quality of education can also be seen from the process because the educational process is considered to determine the immediate and ultimate result of education. The factors of the educational process used as the measurement of the quality must be related to the outcomes both theoretically and empirically.

The process of measuring the education is conducted by examining the quantity and quality with instruments such as observation list, questionnaire and interview. It is similar to the theory proposed by Crosby [13] that the competitive quality of education can be seen from (1) the process, (2) the product and (3) the outcomes generated and perceived by the users of the educational services as well as the industry.

\section{Methods}

This research is qualitative, trying to process the data through descriptive qualitative analysis in both institutional setting and conversation analysis [14]. It aims to examine the various complex elements found in Pondok Pesantren Nurul Jadid Paiton, Probolinggo, which is the leaders' charisma in relation to their success in improving the quality of the pesantren education in both process and output [15]. The research subjects in this research are kyai, ustadz/ustadzah, pesantren secretaries and boarding school administrators in Pondok Pesantren Nurul Jadid Paiton, Probolinggo.

The informants in the current study are chosen based on the following criteria: (1) the subject has a long experience in the field of the targeted research; (2) the subject is still actively involved in the activities of the targeted subjects, such as ustadz (religious teacher), head of the madrasah, and pesantren board;(3) the subject provides free time for an interview related to the information needed; (4) the subject gives real information. Based on these criteria, the determination of sample informants uses purposive sampling techniques, internal sampling, and snowball sampling [16]. The techniques of purposive sampling are used to direct the process of collecting the data according to the need of information. The informants who master the information and problems in depth can be trusted as a source of data.

This study applies several data collection techniques including in-depth interview, participant observation, and documentation. These three techniques are the basis of data collection on qualitative research. This technique has been widely affirmed by many researchers or qualitative authors such as Nasution [17] who certainly tells about the implementation of charismatic leadership and efforts to improve the quality of education in Pondok Pesantren.

This research uses a case study design. Data analysis is conducted by examining the date of the individual site, which is used to analyze the data of every subject in Ponpes Nurul Jadid Paiton, Probolinggo. The process of data analysis is firstly done by reviewing all the data collected from various implemented techniques which are interviews, observations and documentation recorded in the field notes. It is in line with [16] view that data analysis is a systematic process of searching and compiling transcripts of interviews, field notes, and other accumulated materials to improve understanding so that the findings are ready to be presented.

The characteristics of this study are qualitative that the technique of data analysis employs an interactive pattern consisting of three activities; data reduction, data presentation, and conclusion/verification. This Pattern of analysis is based on the following ideas of Miles and Huberman [18]:

1) Data Reduction. Data reduction is done to review all field notes obtained through interviews, observations, 
and documentation studies, then it is summarised in the main or important matters related to the core or focus of research.

2) Data Presentation. Data presentation is a collection of information compiled more systematically in the summarised data reduction. The presentation of this data allows researchers to draw conclusions or take further action. Miles and Huberman [18] assert, "a data display occurring more in qualitative research is a narrative text form." If there are many data collected, the researcher has no difficulty in the mastery of information either whole or certain parts. The result is in the form of narration, images, matrices, or tables which is easily understood and interested.

3) Data Analysis. It is an activity like the conclusion. To further solidify the results of the conclusion, the researchers verify with member checks and triangulation which involve the informants. The researcher checks the validity of the conclusions due to a large number of leaders in Pondok Pesantren.

\section{Discussion and Findings}

The findings of this research show that to improve the quality of the education process, the leader of Nurul Jadid Paiton Probolinggo, in both the institution and pesantren level, plans several efforts to achieve the target through several programs which include developing the competence of educators (ustadz/ ustadzah), the facilities, and the visiting teacher programs from abroad for the students and teachers. It can be more comprehensively analysed as follows:

\subsection{Developing Teachers' (Ustadz/Ustadzah) Competence}

As previously described that the leader of Pondok Pesantren Nurul Jadid provides an opportunity to all ustadz/ ustadzah to pursue their study through dual mode system and master degree scholarship program in both domestic and abroad (the Middle East and Europe).Besides, it provides training for secondary competencies (additional) through several programs such as training in astronomy and curriculum of madrasah in pesantren. The program developed by the leader is very visionary because he can see the need for human resource quality of the educator as the future asset of the pesantren. The training is conducted to make sure that pesantren can survive according to the needs and challenges over the development of the era. Pesantren Nurul Jadid is one of the centres of modern salaf pesantren in the area of tapalkuda (the eastern salient of Java) which demands the quality development of human resources. It goes in line with Azra and Thaha's [19] statement that the biggest challenge of Islamic educational institutions, especially pesantren, today and future is to make sure that pesantren can follow the development of era which continuously demands the quality human resources. Thus, the other needs will undoubtedly come.

There has been an adequate human resource of educators in Pesantren Nurul Jadid Paiton Probolinggo because 100\% of them are bachelor degree and $57 \%$ are masters and $\mathrm{PhD}$ graduates from Europe (McGill University Canada, and so on) and Asia as well as Middle East (Morocco, Medina, and Egypt). It shows that the leadership process at Nurul Jadid pesantren runs well. It can be assumed by the large commitment of human resources of educators in taking high education by the direction and design of all leaders in pesantren. This is also as reinforced by Mardiyah [4] that an indication of the success of organisational culture can be seen from how big the commitment of the human resources and the achievement of the organisation program designed. It will not be separated from the greatness of the charismatic value of the leader spreading out pesantran education program.

\subsubsection{Developing Education Facilities}

The leader of Pondok Pesantren Nurul Jadid, Paiton Probolinggo develops the educational facilities by classifying the competence in the dormitory into more specific, by which students have special expertise (mahirah) without eliminating other competencies. The specialisation of the dormitory includes: (a) dormitory for language, (b) qiroahal-kutub (reading classical Islamic book), (c) takhassus lil huffadz (dormitory for those who memorise Qur'an), and (d) the library of al-qutub at-turast. The classification seems effective because of the four dorms are the fundamental needs of pesantren salafiah and modern. Pondok Pesantren Nurul Jadid has been historically a traditional pesantren which strongly holds the tradition of salafusshalihin, but, on the other hand, it is also very dynamic with the development and challenges of education, in a local, national, and international context. Muhaimin [2] confirms that the existence of Islamic educational institutions is very dependent on the ability to adapt to the development of era and challenges of globalisation which not only demands skill in on science but also international language as the 'common sense' of international people.

The view is futuristically very much in line with the current reality, where almost all Islamic educational institutions are advanced and able to compete at the national and international levels. It indicates that they can develop their human resources, either educators or the students (output), with various capabilities. The fact that Pesantren Nurul Jadid Paiton Probolinggo has been able to make the students success with high achievements, such as being awarded a scholarship to Europe, Asia and the Middle East, indicates that the leader can successfully develop various educational facilities and media needed by the students to compete in the national and international competition arena. 


\subsubsection{Developing Visiting Teacher Program}

In addition to developing the quality of human resources and facilities, to improve the quality of the education, the leader of Pondok Pesantren Nurul Jadid, Paiton Probolinggo also develops visiting teacher program from the Middle East and Europe for santri (student) and teachers every $2-3$ month consistently. This program is intended to strengthen the quality of education. It can be regarded as one of the leading programs because it is not common for Islamic educational institutions, especially pesantren, to present the academic sphere with a relatively strong image of pesantren. The program is conducted regularly by presenting several high-quality speakers from abroad. For the researcher, this program is very useful to support the horizons of scientific knowledge and the insight of students and teachers about the development of contemporary science to master by anyone who wants success in this modern life. Umiarso and Nurzazin [20] states that in the current globalisation, pesantren is required to be able to offer various developments of science and global insight that santri become literate with the globalisation development early. It is hoped that santri already have adequate knowledge supplies to face the global competition in the future.

Visiting Teacher Program is supposed to be continuously and simultaneously conserved and developed in both quantity and quality. The program will become one of the leading programs besides regular education which has been running before. It will not only enable Nurul Jadid to guarantee the future of their students but also enrich the international network, which is beneficial for the institution, students, and alumni in the future.

\subsection{Charismatic Leadership in Improving the Supervising Quality in Pondok Pesantren Nurul Jadid Paiton Probolinggo}

The finding of this research confirms that to improve the quality of education, the leaders of Pesantren Nurul Jadid, both school and institution leader, have outlined several efforts to develop the system and quality time for supervising. Several such programs can be more comprehensively analysed as follows:

\subsubsection{Developing Supervising System}

To increase the supervising system, the leaders of Pesantren Nurul Jadid, Paiton Probolinggo apply several approaches: (a) Developing a dormitory-based supervising system where the comparison between the supervisors and students is in a dormitory which is 2: 20-40. (b) Developing the supervising system based on the number of mentors and students which is 1:15, and (c) developing an integrated/ centralised supervising system under the provision of kiai. The three approaches are applied and developed in an integrated way. With the development of a complex-based supervising system, the balance ratio between the number of the educators and students, and the fact that it is centrally integrated under the control kiai will effectively control and monitor the students. In addition, the supervising process is conducted in stages and gradual so that it is more effective in both the learning process and psychological development of the students. Arifin and Selamet [21] affirm that pesantren needs to consider the various needs of students, including the need for psychological development, so that students can learn optimally.

The above description also implies that the integration of the supervising system applied and developed by Pondok Pesantren Nurul Jadid leads to the maximum quality control, monitoring, and evaluation on the learning achievement of the students during their stay in pesantren. Thus, the quality of supervision will always be well-monitored and sustained. As a highly regarded Islamic educational institution in the eastern salient of Java, Nurul Jadid with the integral and multi-layered supervising system has always been able to maintain the supervising quality of pesantren in the increasing global competition on education and the challenges of the students' morality which remains worse and worse.

\subsubsection{Developing Supervision Program}

As a modern traditional boarding school which consistently maintains the quality development of education, the leader of Pondok Pesantren Nurul Jadid also strives to increase the supervision quality through a number of programs: (a) Muhadarah; (b) Takrir; (c) Qiraah sab'ah/ tadarus (in-turn reading) of Qur'an; (d) Istighasah; and (e) Thoriqoh Program. The programs are integrated because it tries to integrate the model of traditional boarding school programs such as tadarrus, istighasah, thoriqoh with a number of relatively new programs such as takrir, qiro'ah $s a b$ 'ah, and muhadarah as the identity of modernity. Along with the increasing challenges in education, the quality development of supervision programs of Pondok Pesantren Nurul Jadid Paiton Probolinggo is increasingly dynamic in accordance with the needs, and the potential of santri is increasingly diverse. Thus, it is common that this boarding school has long been able to produce alumni with high integrity, not only in the aspect of the knowledge but also principles of adiluhung as which is the main characteristic of pesantren in Indonesia. It is reinforced by Chirzin [22] that the model of supervision developed by pesantren determines the quality of the students' knowledge and morality. The more integrated the program is, the more possible for the students to develop more dynamically and to be more responsive towards various changes among society.

This view strengthens the image of Pesantren Nurul Jadid Paiton Probolinggo as one of the most dynamic Islamic institutions. It also concerns the changes and development of education in the society, especially in meeting the various needs of competence development and 
interest of the students. Pesantren Nurul Jadid, one of the favourite Islamic educational institutions, tries to do the best with diverse and creative efforts based on public interest.

\subsubsection{Developing Quality Time for Supervision}

In addition to the supervision system and programs, the leaders of Pondok Pesantren Nurul Jadid also apply quality time for student supervision with two options (a) 24-hour supervision a day for all students who stays in the dormitory, and (b)12-hours supervision for those who don't stay. The policy already meets the needs of students and supervisors. Besides, the boarding school has strategically empowered and exploits the potential of all teachers, those who stay both in and out of pesantren, as much as possible. Those who stay in pesantren should be unmerged yet so that they can serve to supervise the students in the boarding school. On the other hand, those who don't stay in the boarding school, who are mostly married and not on the board, are more flexible compared to others. According to Nasir and Abdushomad [9], it is a moderate and accommodative policy of pesantren in seeking the potentials of human resources which will ultimately have more positive impacts on pesantren because it highly respects the diversity of human resources without neglecting the quality of education.

The effort to develop the quality of supervision is successfully executed. One of the indications is the active role of the boards in the overall supervision program implemented in the boarding school. Even, it is rare to find an absent supervisor or those who do not do supervision. Even if they are sometimes absent, it must be due to illness, or they are mandated to do another thing outside pesantren, such as taking training and so forth. Pondok Pesantren Nurul Jadid Paiton Probolinggo also does the process of control to all educators and supervisors, and it leads into the balance of the quality control.

\subsection{Charismatic Leadership in Improving the Output Quality of Education in Pondok Pesantren Nurul Jadid Paiton Probolinggo}

To improve the quality of pesantren educational outcomes, the leader of Pesantren Nurul Jadid Paiton Probolinggo, both the school and institution, has outlined a number of efforts to strengthen the competence of alumni/graduate, the network cooperation among alumni, and the network cooperation among pesantren in Indonesia and the world Islamic organisation. The efforts can be more comprehensively analysed as follows:

\subsubsection{Strengthening the Competence of Alumni/ Pesantren Graduates}

An Islamic educational institution with a good futuristic orientation will undoubtedly think about the future of the alumni or alumni candidates. An institution believes that alumni will also have a big contribution to the pesantren image, and so does Pondok Pesantren Nurul Jadid. It has done various kinds of sustainable programs to raise an image of an excellent product of the alumni or alumni candidate. The leader of Pondok Pesantren Nurul Jadid, Paiton Probolinggo strengthens the competence of the alumni/graduates through several programs. They are entrepreneurship training and community service in both internal and external pesantren. The programs are good and considered as 'supporting skills' needed by alumni or alumni candidates. Entrepreneurship becomes the biggest challenge to decrease unemployment in Indonesia. Nasir and Abdushomad [9] asserts that the idealism of pesantren education which must be kept and developed is not trapped in the formal educational routines only, like what most pesantren do in general, without paying attention to the future of their students. So, to achieve the idealism of pesantren education, entrepreneurship development is undoubtedly needed according to the development of the current trend.

The view is very much related to what the leader of Nurul Jadid has done with the entrepreneurship program and community service. They have made cooperation with some elements of society or professional business institutions in strengthening the program such as entrepreneurship institutions in retail, agro-tourism, BMT, and so forth. On the other hand, community service programs oriented to strengthen the main competence of alumni/alumni candidates are seriously taken into account by cooperating with several educational institutions outside and inside the boarding school. It indicates that the efforts to strengthen the alumni have been running well. The data of the alumni dissemination mostly benefited by the community, working and pursuing the study to a higher level, in Indonesia and abroad.

\subsubsection{Strengthening the Network of Alumni}

In addition to developing the competence of alumni through entrepreneurship and community service program, the leader of Pondok Pesantren Nurul Jadid strengthens the network of alumni at regional, national, and international levels through briefing the alumni's career and strengthening the role of the alumni in the community. The effort is highly crucial, and it has been done continuously and simultaneously by Pesantren Nurul Jadid. It is believed that the network of the alumni will also support the development of the pesantren. Besides, it will further ease the burden and duty of pesantren to create a good image of the alumni in public. Ali, Abdussakir and In'am Esha [7] view that the cooperation network of Islamic educational institutions, especially pesantren with the alumni in various regions, will make a good contribution to pesantren if it is simultaneously and continuously done. The view is based on the fact that the alumni network is a simple profile of the quality of the alumni.

A lot of efforts to keep the network of alumni have been 
conducted by Pondok Pesantren Nurul Jadid in various regions. The program scan establishes 47 alumni networks, in both domestic and overseas such as Medina, Egypt, Canada, Singapore, Malaysia, and so on. The entire alumni network (the organisation of alumni of Pesantren Nurul Jadid) actively conducts various programs and participates in training, scientific knowledge, and other program to support the educational program of pesantren.

\subsubsection{Strengthening the Network between Pesantren and Islamic Organization}

As one of the largest Islamic educational institutions in the eastern salient of Java, Pondok Pesantren Nurul Jadid Paiton Probolinggo is very creative in creating the image of excellent educational institutions. In addition to strengthening the quality of the alumni and the network, this boarding school also establishes a cooperation network among pesantren in Indonesia and the World Islamic Organization through several programs including MoU for alumni to become teachers and to have further study in the universities. Both programs keep the cooperation network among Islamic boarding schools all over the world to take the alumni candidates into a future successful career. Through a certain cooperation with several organisations, Pesantren Nurul Jadid can ensure the 'sustainable destiny' of some alumni spread in various regions. According to Azra and Thaha [19], cross-institutional cooperation is an absolute prerequisite for Islamic educational institutions in today's globalisation era to create a more competitive institution because the number of the cross-institutional networks is also a form of recognition on the existence of Islamic educational institutions.

Various efforts are made to strengthen the cooperation between the Islamic boarding school and the world Islamic organisation. They have been implemented in Pondok Pesantren Nurul Jadid. This is based on the fact that all the cooperation are still running well, such as sending the alumni to teach in some boarding schools outside Nurul Jadid and to pursue the study in the Middle East, Asia and Europe. Particularly nearly 20-40 santri are accepted for higher study in Morocco, Sudan, and other middle east countries each year. It illustrates the high recognition of the world Islamic education organisation towards the alumni profile of Pondok Pesantren Nurul Jadid Paiton Probolinggo East Java.

\section{Conclusions}

The overall data exposure and the result of the data analysis concluded that:

1. The charismatic leadership of Pondok Pesantren Nurul Jadid Paiton, Probolinggo in improving the quality of the educational process is conducted in a number of the following programs: a. The leader develops the competence of the teachers by allowing them to pursue their study through 'dual mode system' and master degree scholarship program in both domestic and abroad (the Middle East and Europe). Besides, he provides secondary competence enrichment through several training programs such as training in astronomy, training in the curriculum of the madrasah, and so forth.

b. The leader increases the education facilities by specialising the dormitory based on the students' competence. Thus, they have special skills (mahirah) without eliminating other competencies. The competence specialisation includes language dormitory, qiroah al-kutub, takhassus li lhuffadz, and a library for kutub at-turast.

c. The leader establishes visiting teacher program from the Middle East and Europe for the students and teachers every 2-3 months consistently to strengthen the quality of the educational process.

2. Charismatic leadership in improving the quality of supervision education is conducted in a number of the following programs:

a. The leader develops a supervising system with several approaches. They are: (a) developing a dormitory-based supervising system where the comparison between the supervisors and students in one dormitory is 2: 20-40; (b) developing a supervising system based on the comparison number of mentors with the students, which is 1:15; and (c) developing an integrated/centralized supervising system through the supervision of the main kiai which involves all santri.

b. The leader develops the quality of the supervision program through a number of programs: Muhadarah, Takrir, Qiraah sab'ah/tadarus Al-Qur'an, Istighasah, and Thoriqoh.

c. The leader develops quality time for student supervision with two options of times: a) 24-hour supervision a day for all supervisors who stays in the boarding school complex, and b) 12-hour supervision for those who don't stay in the complex.

3. Charismatic leadership in improving the quality of the education output is enacted in a number of the following programs:

a. The Leader develops the competence of the alumni/graduates through entrepreneurship training and community service in both internal and external pesantren.

b. The leader strengthens the alumni network regional, national or international level - through 
guiding and briefing on their career and strengthening their role among the society.

c. The leader strengthens the cooperation network among pesantren in Indonesia and Islamic organisation all over the world for the alumni/graduates by establishing a MoU for alumni to be teachers and $\mathrm{MoU}$ for further pursuit of study in universities in both Indonesia and abroad.

\section{REFERENCES}

[1] Colling, C.C.: 'Teaching quality revisited: Warnock words for policy practice', Quality Assurance in Education, 1993, $1,(3)$, pp. $21-25$

[2] Muhaimin: 'Manajemen Pendidikan Islam: Sebuah Kerangka Pengembangan Pendidikan Islam' (Pustaka Pelajar, 2004. 2004)

[3] Weber, M.: 'The theory of social and economic organization, trans.' (AM Henderson and Talcott Parsons 1947. 1947)

[4] Mardiyah, M.: 'Kepemimpinan Kiai dalam Memelihara Budaya Organisasi di Pondok Modern Gontor, Lirboyo Kediri, dan Pesantren T ebuireng Jombang', TSAQAFAH, 2012, 8, (1), pp. 67-104

[5] Conger, J.A.: 'Leadership: The art of empowering others', Academy of Management Perspectives, 1989, 3, (1), pp. $17-24$

[6] Yukl, G.: 'Kepemimpinan dalam Organisasi, edisi kelima', Jakarta: PT. Indeks, 2010

[7] Ali, S., Abdussakir, and In'am Esha, M.: 'Paradigma pesantren: memperluas horizon kajian dan aksi' (UIN Maliki Press, 2013. 2013)

[8] Ziemek, M.: 'Pesantren dalam perubahan Sosial' (Perhimpunan Pengembangan Pesantren dan Masyarakat (P3M), 1986. 1986)

[9] Nasir, M.R., and Abdushomad, M.A.: 'Mencari Tipologi Format Pendidikan Ideal: Pondok Pesantren di Tengah Arus Perubahan' (Pustaka Pelajar, 2005. 2005)

[10] Azm, U.B.: 'Kepemimpinan Kharismatik dalam Perspektif Pendidikan Islam' (Kencana Media, 2013. 2013)

[11] Tampubolon, D.P.: 'Perguruan tinggi bermutu: Paradigma baru manajemen pendidikan tinggi menghadapi tantangan abad ke-21' (Gramedia Pustaka Utama, 2001. 2001)

[12] Atkinson, T.: 'Evaluating Quality Circles in a College of Further Education. Manchester Monographs 31' (ERIC, 1990. 1990)

[13] Crosby, P.: 'Quality is free, Mentor', in Editor (Ed. $)^{\wedge}($ Eds.): 'Book Quality is free, Mentor' (McGraw-Hill, New York, NY, 1980, edn.), pp.

[14] Ritzer, G., and Stepnisky, J.: 'Modern sociological theory' (Sage publications, 2017. 2017)
[15] Holliday, A.: 'Doing \& writing qualitative research' (Sage, 2007. 2007)

[16] Biklen, S.K.: 'Qualitative research for education: An introduction to theory and methods' (Allyn and Bacon, 1992. 1992)

[17] Nasution, S.: 'Metode Penelitian Kualitatif Naturalistik', Bandung: Penerbit Tarsito, 1992

[18] Miles, M.B., and Huberman, A.M.: 'Analisis data kualitatif', in Editor (Ed.) ^ (Eds.): 'Book Analisis data kualitatif' (Jakarta: UI press, 1992, edn.), pp.

[19] Azra, A., and Thaha, I.: 'Pendidikan Islam: Tradisi dan Modernisasi di Tengah Tantangan Milenium III . Jakarta', Kencana Prenada Media Group Jakarta, 2012

[20] Umiarso, and Nurzazin, N.: 'Pesantren di Tengah Arus Mutu Pendidikan Menjawab Problematika Kontemporer Manajemen Mutu Pesantren', Semarang: RaSAIL Media Group, 2011

[21] Arifin, I., and Selamet, M.: 'Kepemimpinan Kiyai Dalam Perubahan Menejemen Pondok Pesantren: Kasus Ponpes Tebu Ireng', Pustaka Pelajar, 2010

[22] Chirzin, M.H.: 'Agama dan Ilmu dalam Pesantren', dalam Pesantren dan Pembaharuan. Ed. Dawam Rahardjo. Jakarta: LP3ES, 1988 